\title{
A Preliminary Study on the Transformation of Local Investment and Financing Platform in China
}

\author{
Hui Yu \\ School of Economics \\ Sichuan University \\ Chengdu, China
}

\begin{abstract}
Reasonable change and structural transformation is the only way to develop the local investment and financing platform. In recent years, under the influence of economic regulation, fiscal and financial policies, the development direction of local financing platform has important theoretical and practical significance. In this paper, the author studies the status and difficulties of local investment and financing platform, to explore its transformation and development path, and put forward countermeasures and suggestions.
\end{abstract}

Keywords-local investment and financing platform; transformation; development; study

\section{INTRODUCTION}

Financial support is an important basis for the development of new urbanization process, the National Development and Reform Commission Planning Division Deputy Director Chen Yajun has said that in order to promote the new urbanization, stable and diversified financial security mechanism is the most important. Wang Baoan, vice minister of the Ministry of Finance, pointed out that to fulfill the demand for urbanization, financial capital needs to reach 42 trillion by 2020. However, in 2013, in order to fully understand the local government debt growth changes, the National Audit Office of the provinces and cities nationwide debt investigation thoroughly, and issued 36 local government-level government debt audit report. According to statistics, as of the end of 2016, the central and local government debt balance of about 27.33 trillion yuan, according to the National Bureau of Statistics released 2016 GDP initial calculation, the debt ratio of about $36.7 \%$. Even if the contingent liabilities are taken into account, our government debt ratio is about $40 \%$. The local government relies on the transfer of land funds income has been unable to meet the support of the new urbanization needs, therefore, the use of debt to ease the pressure on capital to promote the local investment and financing platform to develop becomes the government's top priority.

Government financing means mainly rely on investment and financing platform. The State Council issued the Opinions on Strengthening Local Government Debt Management (Guo Fa [2014] No. 43) highlighted the need to separate the investment and financing functions of the investment and financing platform. This means that reasonable change and structural transformation is the only way to develop the current investment and financing platform. In this context, this paper focus on the status of local investment and financing platform, problems and their transformation and development path, combined with foreign advanced experience and domestic research, and put forward countermeasures and suggestions.

\section{DEVELOPMENT OF LOCAL INVESTMENT AND FINANCING PLATFORM}

Local investment and financing platform company refers to the local government and its affiliated departments through financial appropriation or injection of land, equity and other assets set up to assume the government investment project financing function, and has an independent legal personality of the economic entity. Local governments solve a certain period of investment funds gap through the establishment of investment and financing platform, as one of the sources of government debt. Investment and financing platform development can be understood as the local government credit and market-oriented financing of a combination of institutional financing of innovation. As a combination of government and market, investment and financing platform not only pursue profit maximization of economic properties, but also provide public services and social attributes. Government and investment and financing platform in the resource injection and income sources are inseparable, and in the field of investment and financing development, investment and financing platform has more natural monopoly and development authorization. For urban construction projects, especially pure public welfare projects, the local government also bears the "pocket" repayment responsibility. It can be said to some extent, local investment and financing platform and local government lips and teeth dependent, with each other. Although it is undeniable that the local investment and financing platform is easy to trigger the risk of government debt, its debt management is widely criticized, but from a comprehensive, dialectical point of view, in a specific historical period, the local investment and financing platform for the emergence of local economic Development has played a certain positive impact and role. As a city infrastructure construction operator, assume the local government a large number of infrastructure (urban roads, bridges, rivers, sports venues, cultural venues) and public service areas of construction and operational tasks. 
Rely on local government equity, the injection of highquality assets to enrich the registered capital, strengthen the asset strength, thereby enhancing the credit rating. The use of government subsidies, tax incentives to improve the financial situation, in close cooperation with financial institutions, through a variety of financing methods to leverage financial capital, has become an effective complement to the lack of government financial resources. At the same time, for the local government to contribute a certain amount of tax revenue.

In accordance with the regional level, investment and financing platform company is divided into provincial, municipal, county three categories. City-level investment and financing platform and the provincial investment and financing platform compared to the regional characteristics more distinct. One is the rich government background. The relevant departments of government officials as the city level investment and financing platform company team members, in order to better promote the project, planning, land use, start, expenditure and other approval procedures and project implementation. But the government officials of the thinking of business management, investment decision-making to the government awareness of the left and right, less real feasibility study and demonstration, political color strong. Second, land revenue is the main source of balance of the project. Commitment to public welfare infrastructure projects, such as water supply and drainage, municipal roads, affordable housing, the lack of their own income, government support and financial subsidies rely on a larger. Third, mixed business caused by government debt is difficult to distinguish.

The government operating items to feed back the nonbusiness projects, there are non-operating projects to obtain government subsidies to make up for the loss of operating items, making the government debt and non-government debt is difficult to distinguish between debt liability is not clear.

Since 2016, our country has introduced a series of regulations and requirements on strengthening the debt management of investment and financing platform. It is strictly forbidden to take the government debt, In the future, the enterprises transformed by the investment and financing platform companies in accordance with the principle of market-oriented financing and debt repayment, to eliminate the government implicit guarantee, to achieve internalization of risk, the borrowing of debt is not included in government debt. The government shall, within the scope of its contribution, perform the duties of the investor or bear the obligations stipulated in the government procurement contract, the government and the social capital cooperation agreement, and shall not be liable for repayment or guarantee for the investment and financing platform. From the objective, the local investment and financing platform form a compaction mechanism for the development.

\section{INVESTMENT AND FINANCING PLATFORM IN THE FINANCING OF THE PROBLEMS.}

With the reform of China 's tax - sharing system in 1994, the local investment and financing platform companies came into being and competing to grow, despite the contradiction between the local government' s power and financial rights, and the local government 's lack of funds and the urgent development of urban infrastructure. With the implementation of the new "Budget Law" and the introduction of the Opinions of the State Council on Strengthening Local Government Debt Management, local debt is included in the budget management, and the government debt system will be tightened. The local investment and financing platform will lose its living space and Features. This paper analyzes the dilemmas, risks and shortcomings.

Local investment and financing platform company as a product with the development of Chinese characteristics, there are macro-level policy, legal and other risks at the micro-level mechanism, management and financing model and other serious problems, the original system, financing, investment, business model Has been unable to adapt to new development requirements.

\section{A. The Existence of Policy Risk}

Beginning in 2014, the central government introduced a series of policies and measures that regulate local government debt. In particular, the State Council "on strengthening the local government debt management views" clearly states: local governments shall not borrow debt through enterprises and institutions, divestment of the financing platform company's government financing functions. By giving the local government in accordance with the law appropriate debt rights, repair the open channel, blocking illegal channels, so as to standardize the role of government debt financing mechanism. Local investment and financing platform for the company to survive one of the business models, that is, after the government to build infrastructure financing to land loans to repay loans, has been challenged.

\section{B. The Legal Risk of Existence}

The new "budget law" in the form of law to the government debt management to the level of governance according to the law, limiting the way of government debt, clearly stipulates that the only way for local governments to issue local government bonds. Local investment and financing platform companies cannot perform debt duties for government debt, borrowed debt will not be included in the government debt sequence, the guarantee is no longer the future land transfer income as a source of repayment, and financing channels gradually narrowed, Market rules for financing, investment, operational survival.

\section{The Internal Mechanism of the Defect}

First, do not have a sound corporate governance structure. The original government background of the local investment and financing platform company, so that its board of 
directors, the board of supervisors in name only, the board of directors and the management of unity, the board only in the external financing and guarantee to fulfill the form of a separate board of directors, the board of supervisors have a vacuum, Regulatory contingency, did not really play the right to balance each other, the role of mutual containment.

Second, the employment mechanism is not flexible. Lack of market-oriented choice of professional management mechanism, the pay system does not have a competitive advantage.

Third, the business model is in urgent need of change. The role of the original urban infrastructure construction operators is too single and limited, the strategic positioning of the fuzzy and corporate culture weakened, the lack of general market owners of the independence and forwardlooking.

Fourth, stick to the financing model in urgent need of innovation. Financial institutions on the local investment and financing platform for the implementation of the name of the company management system, the major commercial banks on the platform of the total amount of corporate loans, and perhaps gradually reduced not allowed to add, strictly limit the new investment and financing platform company credit line. Too much rely on bank loans and other indirect financing difficult to sustain.

\section{Internal and External Environmental Changes Brought about by the Operational Difficulties.}

Due to the prevalence of asset liquidity and capital shortage of the status quo, while the land auction revenue and the existence of intergenerational time and structure and debt maturity does not match the situation, making the local investment and financing platform company once the debt due Concentrated, the capital chain is unusually tight. The original can be tried by the government financial emergency, but the implementation of the new budget law, the government is strictly prohibited from borrowing abroad, therefore, local investment and financing platform companies rely solely on government land revenue continued mobility is no longer viable. Public welfare projects and other cash flow is difficult to cover costs, a large number of infrastructure projects difficult to obtain bank credit, through the use of loans to change loans, the use of trust funds and other shadow bank funds to raise funds, financing costs rise, debt snowball more and more.

\section{RESEARCH ON THE TRANSFORMATION PATH OF \\ INVESTMENT AND FINANCING PLATFORM COMPANY}

In view of the reform and transformation of local investment and financing platform, many scholars put forward the proposal of platform reform. The main points are as follows: 1) The local government needs to change its function from "economic construction" to "public service" 2) the efficiency of local government financing platform can be achieved through asset securitization;3) to improve the financing platform; 4) to improve the efficiency of the local government financing system; 5) to improve the local officials of the performance evaluation system; 6) gradually stripping the financing function of the local financing platform government; 7) to retain some of the government financing functions and so on. According to the existing research results, it can be found that the direction of investment and financing platform generally includes: the participation of ordinary enterprises in the people's livelihood construction projects, multi-channel development of local public resources, management and operation of public welfare state-owned assets, capital-based investment operations operating state.

\section{A. The Operation of State-owned Capital Company}

With reference to the Singapore Temasek Holdings (Private) Limited model, combined with China's national conditions, local investment and financing platform companies can integrate a decentralized state-owned enterprises in the region, set up a state-owned capital operation company, build a bridge between government and enterprises, Way to gradually change the way to operate capital, in order to achieve the local investment and financing platform for the company's new transformation. Local investment and financing platform companies in the state-owned capital operation can play a bearing on the role. The government is responsible for the government, commissioned by the government commissioned the management of state-owned enterprises, Kai, the ownership of enterprises as a link for the management of the local SASAC on behalf of the government as a local financing platform company's investors, in accordance with the stateowned assets law to exercise significant Management decision - making power, personnel appointment and removal rights and capital gains. Local investment and financing platform company operate state-owned capital company, because the SASAC state-owned capital operating budget implementation of the main, in order to achieve the ultimate goal of state-owned capital preservation and appreciation.

Investment and financing platform for its subordinate state-owned enterprises in accordance with the proportion of investment, property rights as a link, the use of market rules management enterprises. Affiliated companies can be based on the nature of the operation, the formation of a wide range of operating entities, such as industrial investment-based state-owned investment companies; financial, insurance, securities, security-based financial holding company; infrastructure investment and financing-based construction investment companies. The positioning of these roles and the innovation of the model depends on the construction of effective corporate governance mechanism, as well as the establishment of a standardized corporate system, including independent and perfect board system, market-oriented mechanism of the employment system, to use the marketoriented business philosophy and achieve investment and financing model innovation and industrial model innovation. 


\section{B. Participate in Government and Social Capital Cooperation Model (PPP Model)}

As the main market of the local government investment and financing platform, the role of the PPP model in the following two categories:

1) As a social partner, participate in cooperation projects outside the level of government: Local investment and financing platform. If the company is located as a social partner, you can assume the higher level government and subordinate government PPP cooperation projects, as a social capital to participate in the bidding. And with its own nature, such as its state-owned or state-owned holding company type, but also try to participate as a state-owned enterprises in the tender, and has a specific industry characteristics, with the construction capacity, financing capacity, operation and management, comprehensive strength only with the bid Qualification, invisible, for the original only the financing function, not involved in the project management experience in the local investment and financing platform company has a certain challenge.

2) As a cooperative project government capital management of the carrier, the tender selection of social capital: That is, on behalf of the government shares of the project company, the government financial funds can be injected into the local investment and financing platform, commissioned investment and financing platform on behalf of the government shares part of the implementation of the government's project functions. Local investment and financing platform company special local government background, making it as a government representative, is the implementation of government plans and guidelines of the most direct carrier. For the PPP project that requires the joint ownership of government and social capital, the two sides signed a cooperation contract because the government's administrative functions do not have the qualifications of the contractor in the market economy and can entrust the local investment and financing platform to represent the government and make the PPP project as a project Sponsors and social capital together to form SPV company, on behalf of the government to fulfill the functions of shareholders, in accordance with the proportion of equity and social capital co-management of the project company, bear the risk and share the benefits.

3) Play a variety of roles, local investment and financing platform companies in the PPP model of the focus of work: One can be the stock items, and gradually transition to PPP projects, replacement of government debt. Second, the government has given the franchise. Third, we can participate in the level of government PPP cooperation projects outside the investment and operation, and constantly open up new business areas.

\section{The Financial Fund Reform Based on the Main Model}

The local financing platform company is located in the government financial fund reform of the investor side, commissioned by the government, as the representative of the government financial shares of the manager, on behalf of the government funded part of the management fund company, in accordance with the proportion of equity to fulfill the shareholders' rights and obligations, Fund management team in accordance with the market operation of the fund companies in the implementation of investment operations. Local investment and financing with the local economic accumulation of information resources, as the government financial funds support the market of the main body and form fund companies to enlarge the financial efficiency of funds. Over the years, local investment and financing platform companies in the region within the accumulation of familiarity with the stock items facilitate more effective screening projects to play market-oriented support projects. Because of the profit-making nature of the enterprise, making the local investment and financing platform companies in accordance with the rules of the market to select the project, do investment surveys and risk assessment, analysis of revenue, easy to better reflect the nature of service market. Local investment and financing platform company had accumulated investment professional team, investment and financing of advanced management experience, with the market operation of the law to achieve the project investment and choose the right time to exit, so as to further improve the use of funds efficiency. In addition, the quantitative financial funds as part of the equity, through the way of equity and debt leveraging the investment of social capital, you can play a skillfully deflected, to enlarge the role of financial funds.

The development of urbanization is inseparable from the construction of infrastructure, which requires a lot of money, and local financial weakness has a contradiction. Local investment and financing platform to replace the government and banks to carry out financing, and set investment and financing, project construction, operating debt as a whole. From this point of view, the local investment and financing platform is a kind of financial innovation with Chinese characteristics carrier. With its unique historical mission, under the background of the new normal development, it is imperative to change from "economic construction" to "public service" and actively promote the reform of transformation and development.

\section{REFERENCES}

[1] RC Kormendi. Government debt, government spending, and private sector behavior. [J].The American Economy Review,1983.

[2] Tiebout. A pure theory of local expenditures. [J].The journal of political economy.1956

[3] WB Hidreth, GJ Miller. Debt and the local economy: problems in benchmarking local government debt affordability.[J].Public Budgeting\&Finance, 2002(04):99-113.

[4] Moak, Lennox L. Administration of local government debt.[M].Municipal Finance Officers Association of the United States and Canada.1970.

[5] BRIXI H P,SCHICK A. Government at Risk: Gontingent Liabilities and Fiscal Risk[M]. Washington D.C: The World Bank and Oxford University Press,2002:79-98. 
[6] Gang Fan, Yan Lv, Fiscal Prudence and Growth Sustainability: An Analysis of China's Public Debts.[J].Asian Economic Policy Review,2012.

[7] Ho-MouWu, Shiliang Feng. A study of China's Local Government Debt with Regional and Provincial Characteristics.[J].China Economic Journal,2014. 